\title{
Polio outbreak in Tajikistan is cause for alarm
}

Previously published at www.cmaj.ca

$\mathrm{W}$ e are now witnessing the first persistent outbreak of poliomyelitis in the world in a zone previously certified as polio-free. This dreadful disease has no cure and causes paralysis and even death. In April 2010, WHO confirmed that seven children with acute flaccid paralysis in Tajikistan had wild poliovirus type 1. By June 1, a mere five weeks later, over 560 cases of acute flaccid paralysis have been reported, with 183 already laboratory confirmed as WPV-1. This rapidly growing outbreak represents $75 \%$ of the world's cases of poliomyelitis this year, far outstripping usual hotspots in India and Nigeria.

How did this happen in the WHO Euro region, a region certified as polio-free since 2002?

The spread of poliovirus can be insidious, because more than $95 \%$ of infected people are asymptomatic; however, the virus is shed in stool for up to four to eight weeks, which allows it to spread rapidly, widely and initially silently in unimmunized or underimmunized communities. Spread of the virus can only be prevented if more than $90 \%$ of people in a community are vaccinated.

The outbreak appears to have been introduced into Tajikistan from India; the strains most resemble those from Uttar Pradesh, according to genetic typing. ${ }^{2}$ The virus found fertile ground in Tajikistan, where the 2008 rate of uptake of oral polio vaccine was was reported to be $87 \%$, only slightly below the WHO recommended minimum of $90 \%{ }^{2}$ Country-specific averages can be deceptive. In Tajikistan for instance, immunization rates were well below target levels in some regions.

There is now growing concern about the potential for spread of poliomyelitis elsewhere in the world. Too many regions and communities have ceased to worry about polio. As a consequence, rates of vaccine uptake are all too often well below effective prevention levels. As a second precondition, over half a million people from Tajikistan visited over 250 countries last year, according to the Centers for Disease Control (Division of Global Migration and Quarantine). In fact, the epidemic has already spread to Russia as well as neighbouring Uzbekistan.

Although the rates of poliovirus immunization in most of Europe exceed 90\%, neither the Ukraine nor Georgia has reached this target. Furthermore, regions of Canada and some European countries have very low rates of vaccine uptake. Infants and toddlers are often not vaccinated on time because of a lack of appreciation of the seriousness of poliomyelitis. Community immunization rates may also be adversely influenced by concerns about vaccine safety, religious beliefs barring vaccination and antivaccine or antigovernment sentiments.

Enclaves of resistance to vaccination represent a real threat. For example, in Canada in 1978-79, there were 11 instances of flaccid paralysis among unvaccinated people in religious groups in Ontario, Alberta and British Columbia. ${ }^{4}$ The virus did not spread further because of high rates of immunization in the surrounding communities. Since then, complacency has set in. Many people do not fear diseases such as poliomyelitis. In Ontario, rates of immunization in children in the past decade have only hovered between high $70 \%$ to low $80 \%{ }^{5}$ - comparable to rates in Tajikistan when the initial phase of this polio epidemic took hold.

To minimize risks worldwide, we must first control the outbreak in Tajikistan and its surrounding area. With help from WHO, sequential mass polio vaccine campaigns are already under way in Tajikistan. Other countries need to step up their vaccination rates so the overall rates exceed $90 \%$ in all communities. Worldwide surveillance for acute flaccid paralysis should be enhanced to ensure rapid early detection of spread from Tajikistan.

In all countries certified as polio-free, including Canada, the Tajikistan outbreak should be clanging alarm bells. WHO needs to be more proactive than just posting the increasing number of cases on the Global Polio Eradication website (www.polioeradication.org). In our country, it is imperative that the Public Health Agency of Canada issue immediate guidance on the critical importance of being fully vaccinated against polio. Its provincial and territorial counterparts urgently need to ramp up their programs to improve vaccination rates, especially in children, but also for adolescents and adults who are not fully vaccinated. Surveillance programs for acute flaccid paralysis must be on high alert. The threat of polio is no longer simply theoretical.

There are no cures for poliomyelitis - prevention through vaccination is our best and only defence. We are only one asymptomatic infected traveller away from an outbreak because of low vaccination rates.

\section{Noni MacDonald MD MSc}

Section Editor, Public Health, CMAJ

Paul C. Hébert MD MHSc

Editor-in-Chief, CMAJ

With the editorial advisory team: Matthew B. Stanbrook MD PhD and Ken Flegel MDCM MSc

Competing interests: See www.cmaj.ca/misc/edboard.shtml for editorial advisory team statements.

\section{CMAJ 2010. DOI:10.1503/cmaj.100831}

\section{REFERENCES}

1. Collier R. Polio returns to Tajikistan. CMAJ 2010; June 18. Available: www.cmaj.ca/earlyreleases/15june10_polio-returns-to-tajikistan.dtl (accessed 2010 June 18).

2. Outbreak of poliomyelitis in Tajikistan in 2010: risk for importation and impact on polio surveillance in Europe? Eurosurveillance 2010;15:29. pii: 19558. Available: www.eurosurveillance.org/ViewArticle.aspx?ArticleId=19558 (accessed 2010 June 17)

3. Gellin BG, Maibach EW, Marcuse EK. Do parents understand immunizations? A national telephone survey. Pediatrics 2000;106:1097-102.

4. Romain S, Schillaci MA. Childhood immunization. Availability of primary care providers in Ontario. Can Fam Physician 2009;55:1104-5:e4.

5. Vaccine-preventable diseases. Poliomyelitis. Ottawa (ON): Public Health Agency of Canada; 2007. Available: www.phac-aspc.gc.ca/im/vpd-mev/poliomyelitiseng.php (accessed 2010 June 17). 